TITLE:

\title{
DNA barcoding for identification of agarwood source species using trnL-trnF and matK DNA sequences
}

$\operatorname{AUTHOR}(\mathrm{S})$ :

Tanaka, Seiji; Ito, Michiho

\section{CITATION:}

Tanaka, Seiji ... [et al]. DNA barcoding for identification of agarwood source species using trnL-trnF and matK DNA sequences. Journal of Natural Medicines 2020, 74(1): $42-50$

ISSUE DATE:

2020-01

URL:

http://hdl.handle.net/2433/245438

\section{RIGHT:}

This is a post-peer-review, pre-copyedit version of an article published in 'journal of Natural Medicines'. The final authenticated version is available online at: https://doi.org/10.1007/s11418-019-01338-z; The full-text file will be made open to the public on 27 June 2020 in accordance with publisher's 'Terms and Conditions for Self-Archiving'; This is not the published version. Please cite only the published version.; この論文は出版社版でありません。引用の際には出版社 版をご確認ご利用ください。 
Title: DNA barcoding for identification of agarwood source species using trnL-trnF and matK DNA sequences

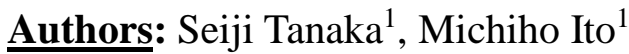

${ }^{1}$ Graduate School of Pharmaceutical Sciences, Kyoto

University, 46-29 Yoshida-Shimoadachi-cho, Sakyo-ku, Kyoto 606-8501, Japan

Corresponding author

Michiho Ito

e-mail:michihoi@pharm.kyoto-u.ac.jp 


\section{Abstract}

2

3 Agarwood is a type of resinous wood found in the trunks of Aquilaria, Gonystylus, and Gyrinops species [1]. High quality agarwood is extraordinarily expensive and therefore its source plant species have become depleted due to exploitation. In 2005, these species were added to Appendix II of the

6 Convention on International Trade in Endangered Species of Wild Fauna and Flora [1]. Because these wild agarwood resources have become depleted, commercial production of agarwood has long been a desirable goal. In addition, inauthentic agarwood is sometimes produced from non-agarwood species.

9 Few reports have attempted to identify source species in order to distinguish genuine from false agarwood. In this study, DNA was extracted from putative agarwood samples collected from Japanese,

11 Indonesian, Thai, and Vietnamese markets. The $\operatorname{trnL}-\operatorname{trn} \mathrm{F}$ region and matK gene were amplified from each sample by PCR to serve as DNA barcodes for identifying the plant species to which each sample

13 belonged. One of the wood samples did not originate from a genuine agarwood species. Although

14 some species were identified, sequence data for agarwood source species currently available in

15 GenBank is insufficient to identify the species to which all of these putative agarwood samples belonged. Thus, positive identification of remaining samples will require further exploration.

\section{Keyword}


1

2 Introduction

3

4

5

6

7

8

9 forms [3]. Whereas, there have been some reports of plant taxonomy using leaves of agarwood source

Agarwood is a type of resinous wood obtained from the trunks of Aquilaria, Gonystylus, and Gyrinops species [1] and has been used as an herbal medicine for sedation, detoxification, treatment for stomachaches or as incense. According to the Japanese Standards for Non-Pharmacopoeial Crude Drugs 2018, 5 species of Aquilaria have been designated as source species for agarwood [2]. Because high quality agarwood is extraordinarily expensive, exploitation of these source species has decreased their abundance in their native environments and in 2005 they were added to Appendix II of CITES [1]. Commercial production of agarwood has long been a desirable goal. However, because agarwood is sometimes produced from wood of non-agarwood source species, the identification of source species has become important. To date, identification of the Aquilaria and Gyrinops species has been carried out by comparing fruit morphology. This method is not particularly suitable for confirming the constituents of agarwood herbal medicines, which normally consist of resin-containing wood pieces. Barcoding techniques for species identification of plants using DNA sequences has become popular, and the availability of DNA sequence data for medicinal plant species has expanded dramatically. Barcoding is useful for identifying the source species of natural medicines and has also been used to detect foreign matter contamination in natural medicines, especially those in small pieces or powder species $[4,5,6,7,8]$, few reports described identification of source species using wood pieces of 
1

8

\section{$9 \quad$ Materials and methods}

10 using the DNeasy Plant Mini Kit (Qiagen, Germany) according to the manufacturer’s protocol. 
1

\section{Primer design}

2

The sequence of primers used for PCR amplifications are shown in Table 3. The trnL-trnF region was

3 amplified using the forward primer A1 and reverse primer A2, and the matK gene was amplified using the forward primer C1 and reverse primer C2. For nested-PCR, the second PCR amplifications were performed using the forward primer B1 and reverse primer B2 within the trnL-trnF region and using the forward primer D1 and reverse primer D2 within the matK gene (Fig. 2).

7

\section{Amplification by PCR}

9 thermocycler. Amplification of PCR products from DNA derived from leaves and dried fruits was achieved using a final reaction volume of $20 \mu \mathrm{L}$ containing $0.5 \mu \mathrm{L}$ of genomic DNA template, $2.0 \mu \mathrm{L}$ of 10× PCR Buffer for KOD Dash, $0.2 \mathrm{mM}$ of dNTPs, $0.2 \mu \mathrm{M}$ each of forward and reverse primers (A1/A2, C1/C2), and $0.5 \mathrm{U}$ of KOD Dash ${ }^{\circledR}$ (Toyobo, Japan). The temperature cycling program for PCR consisted of 1 min at $94^{\circ} \mathrm{C}$, followed by 30 cycles of $30 \mathrm{~s}$ at $94^{\circ} \mathrm{C}, 2 \mathrm{~s}$ at annealing temperature and $30 \mathrm{~s}$ at $74^{\circ} \mathrm{C}$, with a final extension for $1 \mathrm{~min}$ at $72^{\circ} \mathrm{C}$. To amplify PCR products from DNA derived from resin-containing portions of agarwood, the final reaction volume of $20 \mu \mathrm{L}$ contained $2 \mu \mathrm{L}$ of genomic DNA template, $2.0 \mu \mathrm{L}$ of 10× PCR Buffer for KOD -Plus-, $0.2 \mathrm{mM}$ of dNTPs, $1.2 \mu \mathrm{L}$ of $\mathrm{MgSO}_{4}, 0.3 \mu \mathrm{M}$ each of forward and reverse primers (A1/A2, C1/C2), and $0.4 \mathrm{U}$ of KOD -Plus- 
1 of $10 \mathrm{~s}$ at $98^{\circ} \mathrm{C}, 30 \mathrm{~s}$ at annealing temperature and $30 \mathrm{~s}$ at $68^{\circ} \mathrm{C}$. The annealing temperatures for PCR

2 depended on the combinations of primers (Table 4).

3

4 Amplification by nested PCR

5 DNA samples from 6-1 through 6-6 and 7-1 through 7-3 were further amplified after the first

6 amplification. PCR products from the first amplification were applied to PCR clean-up Gel extraction

7 (Macherey-Nagel, Germany) and the DNA concentrations of the purified products were measured

8 using a Qubit 4 Fluorometer (Invitrogen, USA) and adjusted for a second round of PCR. The final

9 reaction volume of $20 \mu \mathrm{L}$ contained $10 \mathrm{ng}$ of genomic DNA template, $2.0 \mu \mathrm{L}$ of $10 \times$ PCR Buffer for

10 KOD -Plus-, $0.2 \mathrm{mM}$ of dNTPs, $1.2 \mu \mathrm{L}$ of $\mathrm{MgSO}_{4}, 0.3 \mu \mathrm{M}$ each of forward and reverse primers (B1/B2

11 D1/D2), and $0.4 \mathrm{U}$ of KOD -Plus-. The temperature cycling program for PCR consisted of 2 min at

$94^{\circ} \mathrm{C}$, followed by 35 cycles of $10 \mathrm{~s}$ at $98^{\circ} \mathrm{C}, 30 \mathrm{~s}$ at annealing temperature, and $30 \mathrm{~s}$ at $68^{\circ} \mathrm{C}$. The

13 annealing temperatures for PCR depended on the combinations of primers (Table 4).

15 DNA sequencing and data analysis

PCR amplification products were separated on 0.5\% agarose/TAE gels, purified using PCR clean-up gel extraction (Macherey-Nagel, Germany) and sequenced on a 3730xl DNA Analyzer using BigDye 
1 leaves and fruits were deposited in GenBank. (Tables 5 and 6)

2

3

4

5

6 Results

7

8 Sequence analyses using DNA extracted from leaves and dried fruits

\section{1. trnL-trnF region}

Samples of leaves and fruits from 18 putative agarwood species were classified into 6 groups according to the DNA sequences of their trnL-trnF regions, and sequence patterns of source species were determined by comparing sequences isolated in the present study with those deposited in GenBank (Table 5). Samples 1-1, 1-2, and 1-3 were morphologically identified as Aquilaria malaccensis but the sequence data for these samples showed that they were actually A. crassna.

Samples 1-4, 1-5, and 1-6 were morphologically identified as A. crassna and this was confirmed by their sequence data. Samples 1-7, 1-8, and 1-9 were morphologically identified as A. sinensis and this was confirmed by their sequence data. Samples 2-1, 2-2, and 2-3 were morphologically identified as

A. malaccensis and this was confirmed by their sequence data. 0Sample 2-4 was morphologically identified as A. malaccensis, but its sequence data showed that it was actually A. microcarpa. Sample 
1

2

3

4

5

6

7

\section{Identification of source species of agarwood samples}

\section{2. trnL-trnF region}

19 species.

\section{2. matK gene} and those from A. crassna and G. versteegii were also identical.

\section{Extraction of DNA} used to amplify PCR products.

sequence data revealed that they were actually Gyrinops versteegii. Sequence data from sample 4-1

differed from the other samples and did not match any GenBank sequences from agarwood source

Eighteen putative agarwood samples were classified into 3 groups according to the DNA sequences of their matK gene (Table 6); results from trnL-trnF regions (Table 5) were combined with those from matK genes and sequences of matK gene deposited in GenBank were further added to make conclusion as Table 6. The DNA sequences of the matK genes in A. malaccensis and A. microcarpa were identical,

Extraction of sufficient DNA from agarwood pieces for amplification by PCR proved difficult (Fig.

3). Adequate PCR products were obtained using DNA extracted from samples 5-1 through 5-6 by changing both the reaction enzyme and program (Fig. 4). However, adequate results were not achieved for samples of 6-1 through 6-6 and 7-1 through 7-3 with this modified protocol so nested PCR was

The trnL-trnF sequences from all 8 samples were identical among leaves and dried fruits and 
1 sequences identical to those from 4 samples were found in GenBank. However, the sequences of the

2 remaining 3 samples included one or more mutations compared with known sequences, and could not

3 be identified (Table 7). In particular, the sequence of sample 5-5 differed substantially from those of

4 other samples in regions other than those shown in the table (Online Resource 1).

\section{3. matK gene}

6 The sequences from 12 out of 15 samples were identical between leaves and dried fruits. For the remaining 3 samples, the sequences of samples 5-3 and 7-3 carried the same mutation and were new to GenBank (Table 8), and the sequence of sample 5-5 again showed very different sequence from those of other samples (Online Resource 1).

\section{Discussion}

\section{Development of genetic identification method using leaves or fruits of agarwood}


1 of samples will be needed to clarify whether our samples belong to the species A. microcarpa.

2 The DNA sequence information found for the matK gene in GenBank (as of March 2019) includes

3104 sequences from Aquilaria species and 2 sequences for Gyrinops species. There is currently very

4 little DNA sequence information for Gyrinops species in GenBank, and the accumulation of more

5 sequence data for this species will be necessary to more definitively identify source species for some

6 samples. The sequence of the matK genes from our study and from GenBank were identical between

7 A. malaccensis, A. microcarpa and A. beccariana and was also identical between A. crassna and G. versteegii, which makes identification of the source species of agarwood using only matK difficult or

9 impossible. Species could not be determined using morphological characteristics or DNA sequences in samples 1-1, 1-2, 1-3, and 2-4. Identifications of samples by only morphological characteristics

11 were provided by agarwood suppliers. This indicates that classification of agarwood source species using morphological characteristics is unreliable, and thus that identification using DNA barcoding will be of significant benefit to the agarwood trade.

Application of DNA barcoding for identification of agarwood source species using

\section{resin-containing wood}

17 Sample 5-2 was predicted to belong to A. beccariana according to the match to its trnL-trnF region in

18 GenBank, but the matK gene of this sample matched A. sinensis. Sample 5-6 was predicted to belong 
1

2

3

4

5

6

7

8

to A. microcarpa based on the sequence match to its $\operatorname{trnL}-\operatorname{trn} \mathrm{F}$ region in GenBank, but its matK sequence matched the $A$. sinensis matK gene. Similarly, samples 6-2 and 6-6 were predicted to belong to G. ledermannii based on the sequence matches of their trnL-trnF regions in GenBank. However, the matK gene of 6-2 matched A. crassna and that of 6-6 matched A. sinensis (Table 9). Those results suggested that samples of 5-2, 5-6, 6-2, and 6-6 might be derived from hybrid plants or that the samples were mixtures of 2 or more species. However, the trnL-trnF region and matK gene are both located on chloroplast DNA and are very likely to be conserved by maternal inheritance. Thus, hybridization is not a likely explanation for the differing species identifications derived from these 2 sequences. An alternative possibility that these samples were mixtures of tissues from multiple plants was ruled out for samples 5-6 and 6-6, which consisted of chunks of wood, but not for samples 5-2 and 6-2, which consisted of small pieces of wood (Table 2). The trnL-trnF and matK sequences of samples 5-3 and 7-3 were identical and were thus considered to belong to the same species. Their sequence patterns were similar to those of other agarwood samples (Tables 7 and 8), although they included deletions of adjacent bases at identical sites within the trnL-trnF region, and no other sequences in GenBank harbor this deletion. These results demonstrate the difficulty of identifying agarwood-producing species, and that increases in the amount of available sequence data for agarwood source species will be useful and may even lead to the identification of additional source species. Interestingly, the sequences of both trnL-trnF and matK from sample 5-5 differed significantly from those of the Aquilaria species. 
1 Although its sequences turned out to be similar to those belonging to the order Thymelaeaceae, sample

2 5-5 could not be classified at the species level. This result indicates that wood from plants that are not

3 agarwood source species is likely introduced into the agarwood market as a false substitute for

4 agarwood. Although fake agarwood has been a common problem, especially when intended for

5 medicinal purposes, identification of source plant species by DNA barcoding could help validate

6 whether material is genuine for purposes of quality and safety assurance. Seven specimens other than

7 the above-mentioned 8 samples of original species identifications based on comparisons of trnL-trnF

8 sequence and those from the matK gene all matched (Table 9). Samples 7-1 and 7-2 were randomly

9 selected specimens from one lot of agarwood pieces purchased at a market in Vietnam and were shown

here to belong to different species (Table 9). This probably occurred because agarwood is collected by

11 brokers before distribution to markets and is classified according to morphological characteristics, resin composition, and other characteristics as the brokers have no other means of confirming the source species of agarwood.

\section{Conclusions}

The results of this study showed a sequence comparison of trnL-trnF region and matK gene can be used to identify agarwood source species, but indicated that the sequences of either one of these regions alone is insufficient for complete identification, due to the inadequacy of sequence data in 
1 accomplished by comparing morphological characteristics of fresh fruits. Thus, after harvest, there

2 was no way to confirm the source species of agarwood without information about the fruit morphology

3 of their source plants. Thus, the information about agarwood source plants often seemed incorrect and

4 species names provided by suppliers often contradicted those from DNA barcoding analyses. The

5 DNA barcoding analyses in this study also revealed that the plant source species of a sample represented as agarwood was not a genuine agarwood species, demonstrating the utility of this method.

7 However, this method requires sequence analysis, which is not always convenient, and insufficient sequence data for agarwood source plant species can make it difficult to positively identify source

9 species. Therefore, increasing the amount of sequence data available for agarwood source species will address this issue. Several attempts have been made to identify source species of agarwood. Eurlings

11 et al. (2005) sought to distinguish agarwood source plant species using trnL-trnF sequence data from old wood specimens but did not describe extraction of DNA from tree trunk or agarwood [4]. Lee et al. (2016) performed DNA analyses of resinous portions of 8 agarwood samples and found that DNA extraction from this tissue took a long time [9]. Lichao et al. (2014) examined the efficacy of DNA extraction according to changes in drying conditions of $A$. sinensis wood, and they also found that DNA extraction took a long time and that the DNA of some samples could not be extracted [10]. DNA from agarwood samples harvested many hundreds of years ago is fragmented, which makes amplification of PCR products difficult. Improving DNA extraction methodology, while necessary, is 
1 often not sufficient for improving amplification. In this study, we obtained PCR products of sufficient

2 quality for sequencing by modifying both the reaction enzyme and temperature cycling program.

3 These modifications were useful for obtaining PCR products from fragmented DNA isolated from

4 tissues exposed to long-term storage, drying, and heat. Our method could also be used to identify other

5 plant species used in natural medicines and powdered herbal medicines that have not previously been

6 analyzed using DNA. For appropriate use of natural resources and also for regulatory purposes, the

7 species identification methods developed in this study could be useful for ensuring the quality and

8 safety of natural medicines, in addition to validating the authenticity of natural materials.

9

\section{References}

1. ANNUAL REPORT OF THE SECRETARIAT 2004, Convention on International Trade in

2. The Ministry of Health, Labour and Welfare (2018) The Japanese standards for non-Pharmacopoeial crude drugs 2018:51.

3. The Ministry of Health, Labour and Welfare (2016) The Japanese pharmacopoeia, 17th edn. The

4. Eurlings MCM, Gravendeel B. (2005) TrnL-trnF sequence data imply paraphyly of Aquilaria and 
1 5. Shiou Yih Lee,1 Maman Turjaman,2 and Rozi Mohamed (2018) Phylogenetic Relatedness of

2 Several Agarwood-Producing Taxa (Thymelaeaceae) from Indonesia. Trop Life Sci Res. 2018 Jul;

3 29(2): 13-28.

4 6. Tingting Feng et al. (2018) Phylogenetic analysis of Aquilaria Lam. (Thymelaeaceae) based on

$5 \quad$ DNA barcoding. Holzforschung 73(6):517-523

6 7. Woratouch Thitikornpong, Chanida Palanuvej, Nijsiri Ruangrungsi (2018) DNA barcoding for

7 authentication of the endangered plants in genus Aquilaria. Thai Journal of Pharmaceutical Sciences,

$8 \quad 42,214-220$

9 8. Qiwei Li et al. (2018) Molecular Identification of Three Aquilaria (Thymelaeaceae) Species through

10 DNA Barcoding Biol. Pharm. Bull., 41, 967-971

11 9. Lee SY, Ng WL, Mahat MN et al. (2016) DNA Barcoding of the Endangered Aquilaria

12 (Thymelaeaceae) and Its Application in Species Authentication of Agarwood Products Traded in the

13 Market. PLoS One;11:e0154631.

14 10. L Jiao, Y Yin, Y Cheng, X Jiang (2014) DNA barcoding for identification of the endangered species

15 Aquilaria sinensis: comparison of data from heated or aged wood samples. Holzforschung 68(4):487-

16494

17 11. Taberlet P., Gielly L., Patou G., Bouvet J. (1991) Universal primers for amplification of three

18 noncoding regions of chloroplast. DNA. Plant Mol. Biol. 17: 1105-1109 
1 12. CBOL Plant Working Group et al. (2009) A DNA barcode for land plants. Proc Natl Acad Sci

\section{Tables}

5 Table 1 Details of leaf and fruit samples from agarwood source species used in this study

\begin{tabular}{|c|c|c|c|c|}
\hline $\begin{array}{l}\text { Sample } \\
\text { No. }\end{array}$ & $\begin{array}{l}\text { Species according } \\
\text { to morphological characteristics }\end{array}$ & Part used & Collection site & Collection date \\
\hline $1-1$ & A. malaccensis & Leaf & Japan & June, 2014 \\
\hline $1-2$ & A. malaccensis & Leaf & Japan & June, 2014 \\
\hline $1-3$ & A. malaccensis & Leaf & Japan & June, 2014 \\
\hline $1-4$ & A. crassna & Leaf & Japan & June, 2014 \\
\hline $1-5$ & A. crassna & Leaf & Japan & June, 2014 \\
\hline $1-6$ & A. crassna & Leaf & Japan & June, 2014 \\
\hline $1-7$ & A. sinensis & Leaf & Japan & June, 2014 \\
\hline $1-8$ & A. sinensis & Leaf & Japan & June, 2014 \\
\hline $1-9$ & A. sinensis & Leaf & Japan & June, 2014 \\
\hline $2-1$ & A. malaccensis & Leaf & Indonesia & February, 2015 \\
\hline $2-2$ & A. malaccensis & Leaf & Indonesia & February, 2015 \\
\hline $2-3$ & A. malaccensis & Leaf & Indonesia & February, 2015 \\
\hline $2-4$ & A. malaccensis & Fruit & Indonesia & February, 2015 \\
\hline $2-5$ & A. microcarpa & Fruit & Indonesia & February, 2015 \\
\hline $3-1$ & Gyrinops. sp. & Leaf & Indonesia & January, 2017 \\
\hline $3-2$ & Gyrinops. sp & Leaf & Indonesia & January, 2017 \\
\hline $3-3$ & Gyrinops. sp. & Leaf & Indonesia & January, 2017 \\
\hline $4-1$ & Unknown & Leaf & Indonesia & February, 2017 \\
\hline
\end{tabular}

6 Samples 1-1 through 1-9 and 2-1 through 2-5 were collected from a greenhouse at the Experimental

7 Station for Medicinal Plants at the Graduate School of Pharmaceutical Science, Kyoto University,

8 Japan 
2 Table 2 Details of forms resin-containing agarwood samples used in this study

\begin{tabular}{lll}
\hline Sample No & Sample type & Collection site \\
\hline $5-1$ & small pieces & Japan \\
$5-2$ & small pieces & Japan \\
$5-3$ & chunk & Thailand \\
$5-4$ & chunk & Indonesia \\
$5-5$ & chunk & Indonesia \\
$5-6$ & chunk & Indonesia \\
$6-1$ & small pieces & Japan \\
$6-2$ & small pieces & Japan \\
$6-3$ & small pieces & Japan \\
$6-4$ & small pieces & Japan \\
$6-5$ & small pieces & Japan \\
$6-6$ & chunk & Japan \\
$7-1$ & chunk & Vietnam \\
$7-2$ & chunk & Vietnam \\
$7-3$ & chunk & Indonesia \\
\hline
\end{tabular}

3

$6 \quad$ Table 3 List of primers used in this study

\begin{tabular}{|c|c|c|c|c|}
\hline $\begin{array}{l}\text { Target } \\
\text { region }\end{array}$ & Code & Name & Sequence $5^{\prime}-3^{\prime}$ & References \\
\hline \multirow{4}{*}{$\operatorname{trnL}-\operatorname{trn} \mathrm{F}$} & A1 & B49873 & 5'-GGTTCAAGTCCCTCTATCCC-3' & [11] \\
\hline & A2 & A50272 & 5'-ATTTGAACTGGTGACACGAG-3' & [11] \\
\hline & B1 & trnLaq & 5'-ACAGGCGTATCCGAGCATCA-3' & This study \\
\hline & B2 & $\operatorname{trnFaq}$ & 5'-CCGACCATTACCAAGACATCATCC-3' & This study \\
\hline \multirow{2}{*}{ matK } & $\mathrm{C} 1$ & 3FKIM_f & 5'-CGTACAGTACTTTTGTGTTTACGAG-3' & [12] \\
\hline & $\mathrm{C} 2$ & 1RKIM_r & 5'-CCCAGTCCATCTGGAAATCTTGGTTC-3' & [12] \\
\hline
\end{tabular}




\begin{tabular}{llll} 
D1 & matkaq_f & 5'-GCAATCTTTCTTGAACGGATCT-3' & This study \\
D2 & matkaq_r & 5'-AATCGACCCAAGTTGGCTTA-3' & This study \\
\hline
\end{tabular}

1

2

3 Table 4 List of primer combinations used in this study

\begin{tabular}{lll}
\hline Combinations & Length of target region & Annealing temperature for PCR \\
\hline A1/A2 & $500 \mathrm{bp}$ & $56{ }^{\circ} \mathrm{C}$ \\
B1/B2 & $300 \mathrm{bp}$ & $56{ }^{\circ} \mathrm{C}$ \\
C1/C2 & $1000 \mathrm{bp}$ & $52{ }^{\circ} \mathrm{C}$ \\
D1/D2 & $500 \mathrm{bp}$ & $56{ }^{\circ} \mathrm{C}$ \\
\hline
\end{tabular}

4

5

6

7

8 Table 5 SNPs in the trnL-trnF IGS region amplified from DNA extracted from leaf and fruit samples

\begin{tabular}{|c|c|c|c|c|c|c|c|c|c|c|}
\hline \multirow{2}{*}{$\begin{array}{l}\text { Sample } \\
\text { No. }\end{array}$} & \multicolumn{8}{|c|}{ SNPs } & \multirow{2}{*}{$\begin{array}{l}\text { Species identified } \\
\text { by DNA sequence }\end{array}$} & \multirow{2}{*}{$\begin{array}{l}\text { Genbank } \\
\text { Accession No. }\end{array}$} \\
\hline & 159 & 291 & 301 & 327 & 328 & 339 & 368 & 381 & & \\
\hline $1-1$ & A & $\mathrm{T}$ & G & $\mathrm{T}$ & - & $\mathrm{T}$ & $\mathrm{C}$ & $\mathrm{C}$ & A. crassna & LC467499 \\
\hline $1-2$ & A & $\mathrm{T}$ & G & $\mathrm{T}$ & - & $\mathrm{T}$ & $\mathrm{C}$ & $\mathrm{C}$ & A. crassna & LC467500 \\
\hline $1-3$ & A & $\mathrm{T}$ & G & $\mathrm{T}$ & - & $\mathrm{T}$ & $\mathrm{C}$ & $\mathrm{C}$ & A. crassna & LC467501 \\
\hline $1-4$ & A & $\mathrm{T}$ & G & $\mathrm{T}$ & - & $\mathrm{T}$ & $\mathrm{C}$ & $\mathrm{C}$ & A. crassna & LC467502 \\
\hline $1-5$ & A & $\mathrm{T}$ & G & $\mathrm{T}$ & - & $\mathrm{T}$ & $\mathrm{C}$ & $\mathrm{C}$ & A. crassna & LC467503 \\
\hline $1-6$ & A & $\mathrm{T}$ & G & $\mathrm{T}$ & - & $\mathrm{T}$ & $\mathrm{C}$ & $\mathrm{C}$ & A. crassna & LC467504 \\
\hline $1-7$ & A & G & $\mathrm{T}$ & $\mathrm{T}$ & $\mathrm{T}$ & $\mathrm{T}$ & A & A & A. sinensis & LC467505 \\
\hline $1-8$ & A & G & $\mathrm{T}$ & $\mathrm{T}$ & $\mathrm{T}$ & $\mathrm{T}$ & A & A & A. sinensis & LC467506 \\
\hline $1-9$ & A & G & $\mathrm{T}$ & $\mathrm{T}$ & $\mathrm{T}$ & $\mathrm{T}$ & A & A & A. sinensis & LC467507 \\
\hline $2-1$ & $\mathrm{C}$ & $\mathrm{T}$ & $\mathrm{T}$ & $\mathrm{T}$ & - & G & $\mathrm{C}$ & A & A. malaccensis & LC467508 \\
\hline $2-2$ & $\mathrm{C}$ & $\mathrm{T}$ & $\mathrm{T}$ & $\mathrm{T}$ & - & G & $\mathrm{C}$ & A & A. malaccensis & LC467509 \\
\hline $2-3$ & $\mathrm{C}$ & $\mathrm{T}$ & $\mathrm{T}$ & $\mathrm{T}$ & - & G & $\mathrm{C}$ & A & A. malaccensis & LC467510 \\
\hline $2-4$ & A & $\mathrm{T}$ & $\mathrm{T}$ & - & - & G & $\mathrm{C}$ & A & A. microcarpa & LC467511 \\
\hline $2-5$ & A & $\mathrm{T}$ & $\mathrm{T}$ & - & - & G & $\mathrm{C}$ & A & A. microcarpa & LC467512 \\
\hline $3-1$ & A & $\mathrm{T}$ & $\mathrm{T}$ & $\mathrm{T}$ & - & $\mathrm{T}$ & $\mathrm{C}$ & A & G. versteegii & LC467513 \\
\hline $3-2$ & A & $\mathrm{T}$ & $\mathrm{T}$ & $\mathrm{T}$ & - & $\mathrm{T}$ & $\mathrm{C}$ & A & G. versteegii & LC467514 \\
\hline $3-3$ & $\mathrm{~A}$ & $\mathrm{~T}$ & $\mathrm{~T}$ & $\mathrm{~T}$ & - & $\mathrm{T}$ & $\mathrm{C}$ & A & G. versteegii & LC467515 \\
\hline
\end{tabular}


1 All samples in this experiment were amplified using the A1/A2 primer combination

3 Table 6 SNPs in the matK region amplified from DNA extracted from leaf and fruit samples

\begin{tabular}{lccccccll}
\hline Sample & \multicolumn{9}{c}{ SNPs } & \multicolumn{3}{c}{ Species identified } & GenBank \\
\cline { 2 - 6 } No. & 156 & 265 & 294 & 358 & 371 & 406 & by DNA sequence & Accession No. \\
\hline $1-1$ & C & C & G & C & C & A & A. crassna & LC467516 \\
$1-2$ & C & C & G & C & C & A & A. crassna & LC467517 \\
$1-3$ & C & C & G & C & C & A & A. crassna & LC467518 \\
$1-4$ & C & C & G & C & C & A & A. crassna & LC467519 \\
$1-5$ & C & C & G & C & C & A & A. crassna & LC467520 \\
$1-6$ & C & C & G & C & C & A & A. crassna & LC467521 \\
$1-7$ & A & T & C & C & A & C & A. sinensis & LC467522 \\
$1-8$ & A & T & C & C & A & C & A. sinensis & LC467523 \\
$1-9$ & A & T & C & C & A & C & A. sinensis & LC467524 \\
$2-1$ & C & C & G & T & C & A & A. malaccensis & LC467525 \\
$2-2$ & C & C & G & T & C & A & A. malaccensis & LC467526 \\
$2-3$ & C & C & G & T & C & A & A. malaccensis & LC467527 \\
$2-4$ & C & C & G & T & C & A & A. microcarpa & LC467528 \\
$2-5$ & C & C & G & T & C & A & A. microcarpa & LC467529 \\
$3-1$ & C & C & G & C & C & A & G. versteegii & LC467530 \\
$3-2$ & C & C & G & C & C & A & G. versteegii & LC467531 \\
$3-3$ & C & C & G & C & C & A & G. versteegii & LC467532 \\
$4-1$ & C & C & G & T & C & A & Unknown & - \\
\hline & & & & & & & &
\end{tabular}

4 All samples in this experiment were amplified using the C1/C2 primer combination

6 Table 7 SNPs in the trnL-trnF IGS region amplified from DNA extracted from extracted from wood

7 samples 


\begin{tabular}{|c|c|c|c|c|c|c|c|c|c|c|}
\hline \multirow[b]{2}{*}{ No. } & \multirow[b]{2}{*}{ combinations } & & \multirow[b]{2}{*}{ by DNA sequence } \\
\hline & & 159 & 291 & 301 & 327 & 328 & 339 & 368 & 381 & \\
\hline $5-1$ & A1/A2 & $\mathrm{C}$ & $\mathrm{T}$ & $\mathrm{T}$ & $\mathrm{T}$ & - & G & $\mathrm{C}$ & A & A. malaccensis \\
\hline $5-2$ & A1/A2 & A & $\mathrm{T}$ & $\mathrm{T}$ & $\mathrm{T}$ & - & G & $\mathrm{C}$ & A & A. beccariana \\
\hline $5-3$ & A1/A2 & A & G & G & $\mathrm{T}$ & - & $\mathrm{T}$ & - & A & Unknown \\
\hline $5-4$ & A1/A2 & $\mathrm{C}$ & $\mathrm{T}$ & $\mathrm{T}$ & $\mathrm{T}$ & - & G & $\mathrm{C}$ & A & A. malaccensis \\
\hline $5-5$ & A1/A2 & A & - & $\mathrm{T}$ & $\mathrm{T}$ & - & - & $\mathrm{C}$ & $\mathrm{T}$ & (Thymelaeaceae) \\
\hline $5-6$ & A1/A2 & $\mathrm{A}$ & $\mathrm{T}$ & $\mathrm{T}$ & - & - & G & $\mathrm{C}$ & A & A. microcarpa \\
\hline $6-1$ & $\mathrm{~A} 1 / \mathrm{A} 2, \mathrm{~B} 1 / \mathrm{B} 2$ & A & $\mathrm{T}$ & $\mathrm{T}$ & $\mathrm{T}$ & - & $\mathrm{T}$ & $\mathrm{C}$ & A & G. versteegii \\
\hline $6-2$ & $\mathrm{~A} 1 / \mathrm{A} 2, \mathrm{~B} 1 / \mathrm{B} 2$ & A & G & $\mathrm{T}$ & $\mathrm{T}$ & $\mathrm{T}$ & $\mathrm{T}$ & $\mathrm{C}$ & A & G. ledermannii \\
\hline $6-3$ & A1/A2, B1/B2 & A & $\mathrm{T}$ & $\mathrm{T}$ & $\mathrm{T}$ & - & $\mathrm{T}$ & $\mathrm{C}$ & A & G. versteegii \\
\hline $6-4$ & A1/A2, B1/B2 & $\mathrm{A}$ & G & $\mathrm{T}$ & $\mathrm{T}$ & $\mathrm{T}$ & $\mathrm{T}$ & A & A & A. sinensis \\
\hline $6-5$ & $\mathrm{~A} 1 / \mathrm{A} 2, \mathrm{~B} 1 / \mathrm{B} 2$ & A & $\mathrm{T}$ & $\mathrm{T}$ & $\mathrm{T}$ & - & $\mathrm{T}$ & $\mathrm{C}$ & A & G. versteegii \\
\hline $6-6$ & A1/A2, B1/B2 & A & G & $\mathrm{T}$ & $\mathrm{T}$ & $\mathrm{T}$ & $\mathrm{T}$ & $\mathrm{C}$ & A & G. ledermannii \\
\hline $7-1$ & A1/A2, B1/B2 & A & $\mathrm{T}$ & $\mathrm{T}$ & $\mathrm{T}$ & - & G & $\mathrm{C}$ & A & A. beccariana \\
\hline $7-2$ & A1/A2, B1/B2 & A & $\mathrm{T}$ & G & $\mathrm{T}$ & - & $\mathrm{T}$ & $\mathrm{C}$ & $\mathrm{C}$ & A. crassna \\
\hline $7-3$ & A1/A2, B1/B2 & A & G & G & $\mathrm{T}$ & - & $\mathrm{T}$ & - & A & Unknown \\
\hline
\end{tabular}

1 The sequence data is shown in Online Resource 1

2 Identification of A. beccariana, and G. ledermannii was based on GenBank sequence data (KT726319)

$3 \quad[4]$ and (AY216755) [4]

4

5

6

$7 \quad$ Table 8 SNPs in the matK region extracted from wood samples

\begin{tabular}{llccccccl}
\hline Sample & Primer & \multicolumn{9}{c}{ SNPs } \\
\cline { 2 - 6 } No. & combinations & 156 & 265 & 294 & 358 & 371 & 406 & by DNA sequence \\
\hline $5-1$ & C1/C2 & C & C & G & T & C & A & A. malaccensis \\
$5-2$ & C1/C2 & A & T & C & C & A & C & A. sinensis \\
$5-3$ & C1/C2 & A & T & C & C & A & A & Unknown \\
$5-4$ & C1/C2 & C & C & G & T & C & A & A. malaccensis \\
$5-5$ & C1/C2 & T & C & C & A & C & A & (Thymelaeaceae) \\
$5-6$ & C1/C2 & A & T & C & C & A & C & A. sinensis \\
6-1 & C1/C2, D1/D2 & / & C & G & C & C & A & G. versteegii
\end{tabular}




\begin{tabular}{lllllllll} 
6-2 & C1/C2, D1/D2 & / & C & G & C & C & A & G. versteegii \\
6-3 & C1/C2, D1/D2 & / & C & G & C & C & A & G. versteegii \\
6-4 & C1/C2, D1/D2 & / & T & C & C & A & C & A. sinensis \\
6-5 & C1/C2, D1/D2 & / & C & G & C & C & A & G. versteegii \\
6-6 & C1/C2, D1/D2 & / & T & C & C & A & C & A. sinensis \\
$7-1$ & C1/C2, D1/D2 & / & C & G & T & C & A & A. beccariana \\
7-2 & C1/C2, D1/D2 & / & C & G & C & C & A & A. crassna \\
$7-3$ & C1/C2, D1/D2 & / & T & C & C & A & A & Unknown \\
\hline
\end{tabular}

1 The sequence data is shown in Online Resource 1

2 We were unable to analyze 156 base pairs when samples were amplified with the D1/D2 primer

3 combination

4 Identification of $A$. beccariana, was based on GenBank sequence data (FJ572802)

5 *The DNA sequences of the matK genes in A. malaccensis and A. beccariana were identical

6

7

8 Table 9 Comparison of species identifications based on trnL-trnF or matK regions

Sample Species identification based on Species identification based on

No. sequence of $\operatorname{trnL-trnF}$ region sequence of $\boldsymbol{m a t K}$ region

\begin{tabular}{lll}
\hline $5-1$ & A. malaccensis & A. malaccensis \\
$5-2$ & A. beccariana & A. sinensis \\
$5-3$ & Unknown & Unknown \\
$5-4$ & A. malaccensis & A. malaccensis \\
$5-5$ & (Thymelaeaceae) & (Thymelaeaceae) \\
$5-6$ & A. microcarpa & A. sinensis \\
$6-1$ & G. versteegii & G. versteegii \\
6-2 & G. ledermannii & G. versteegii \\
$6-3$ & G. versteegii & G. versteegii \\
6-4 & A. sinensis & A. sinensis \\
$6-5$ & G. versteegii & G. versteegii \\
$6-6$ & G. ledermannii & A. sinensis
\end{tabular}




\begin{tabular}{lll}
$7-1$ & A. beccariana & A. beccariana \\
$7-2$ & A. crassna & A. crassna \\
$7-3$ & Unknown & Unknown \\
\hline
\end{tabular}

1

2 Figure legends

3 Fig. 1 Examples of morphology of agarwood samples used in this study

4 Fig. 2 Positions and directions of primers used for amplifying the trnL-trnF IGS region and the matK

5 gene

$6 \quad$ Fig. 3 DNA samples extracted from plant materials

7 Fig. 4 PCR products amplified from extracted DNA separated by agarose-gel electrophoresis 
Fig. 1

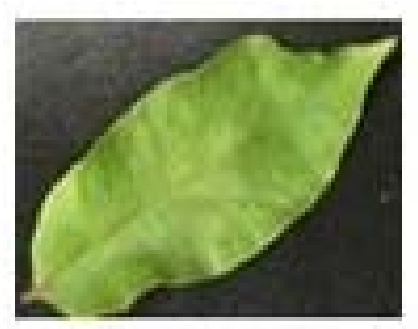

Leaf sample

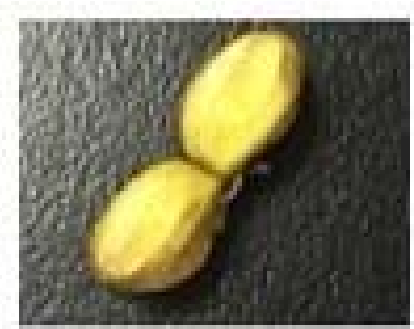

Fruit sample
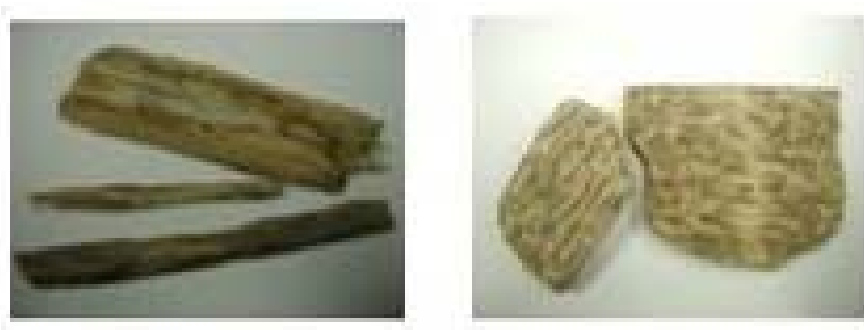

Wood samples

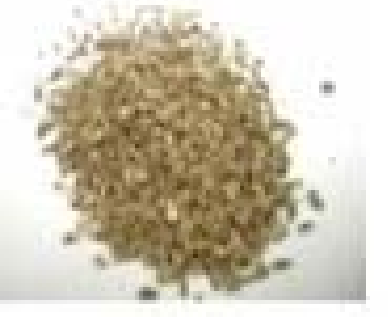


Fig. 2

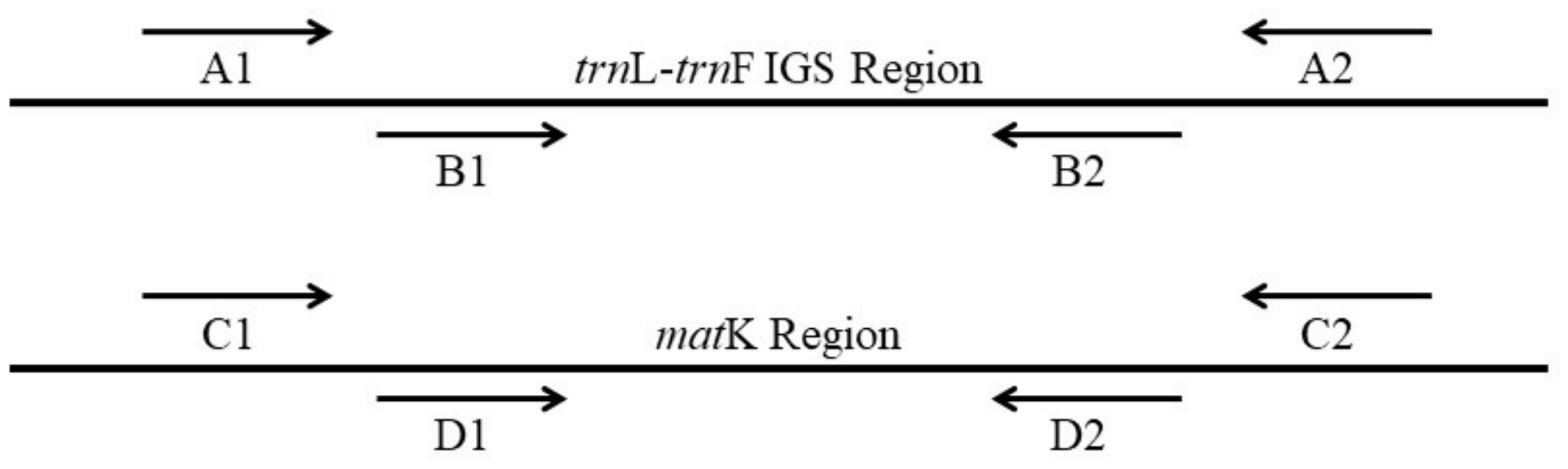


Fig. 3

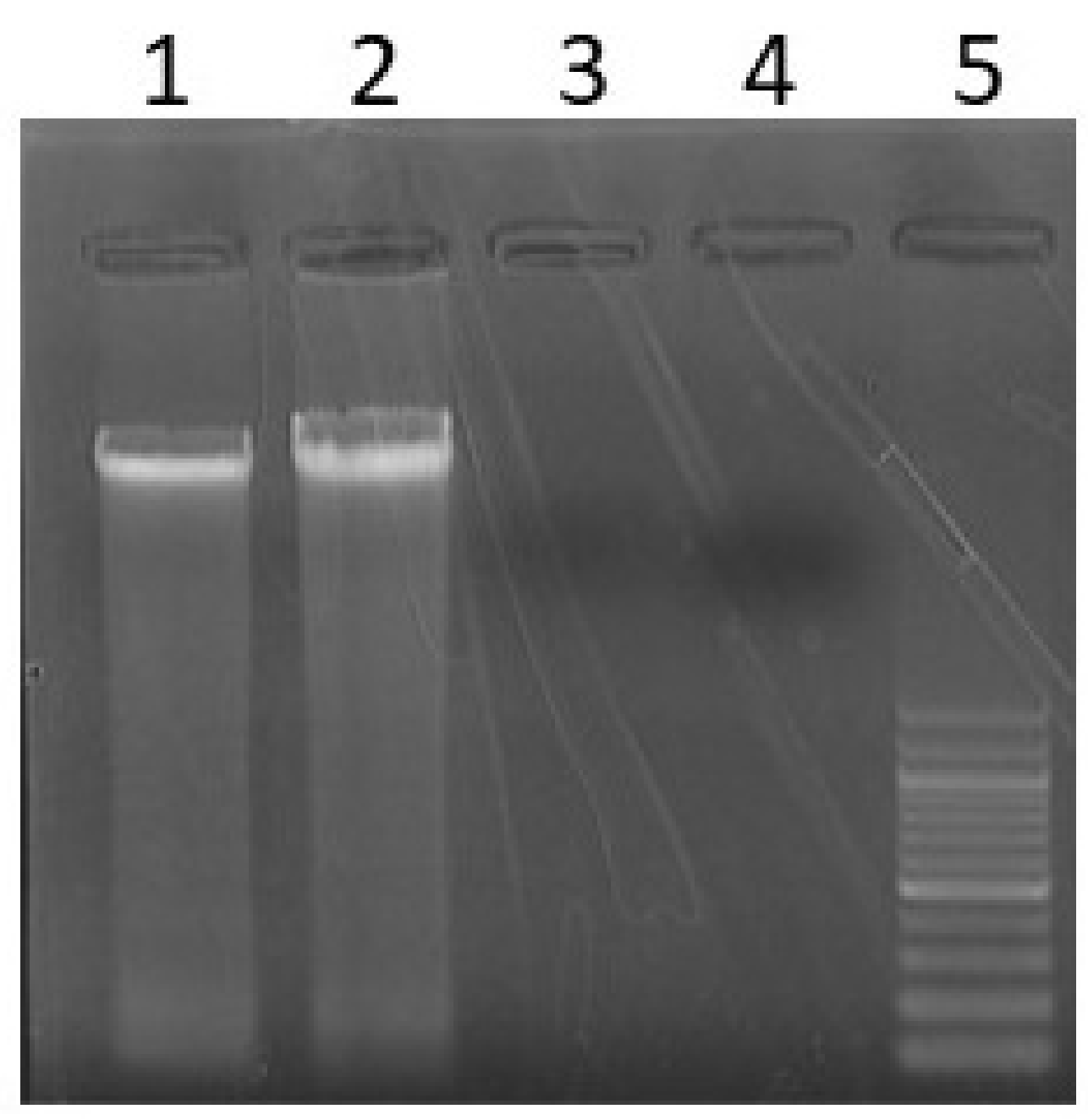

Lane 1: leaf or fruit

Lane 2: leaf or fruit

Lane 3: wood

Lane 4: wood

Lane 5: 100 bp DNAladder 
Fig. 4

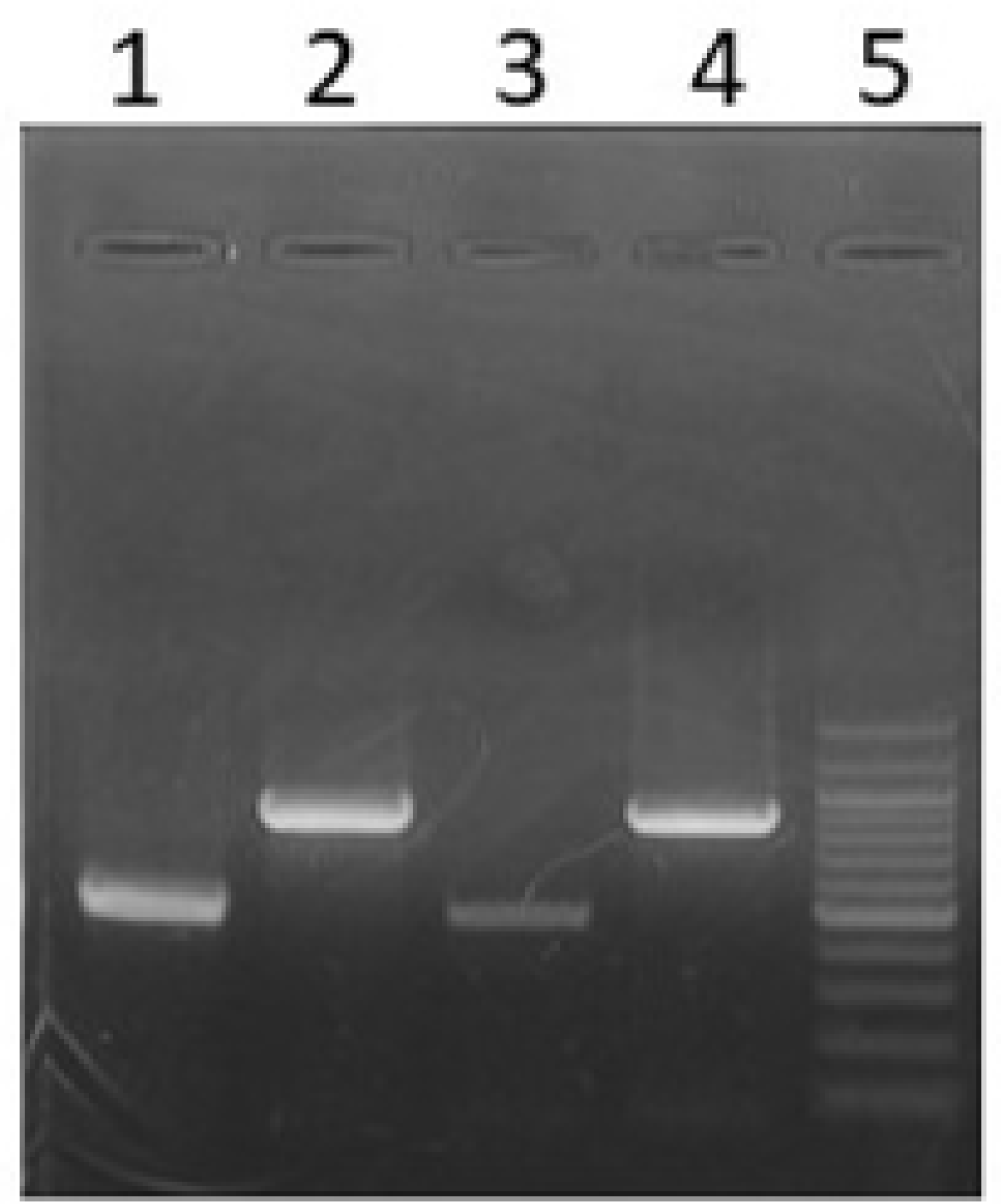

Lane 1: leaf or fruit by $A 1 / A 2$

Lane 2: leaf or fruit by $\mathrm{Cl} / \mathrm{C} 2$

Lane 3: wood by $A 1 / A 2$

Lane 4: wood by C1/C2

Lane 5: 100 bp DNA ladder 